\title{
Chemical composition and antibacterial activity of essential oil and leaf extracts of Zanthoxylum caribaeum Lam. against serotypes of Salmonella
}

\author{
Composição química e atividade antibacteriana do óleo essencial e extratos vegetais \\ das folhas de "Zanthoxylum caribaeum" Lam. frente a sorotipos de "Salmonella"
}

\author{
SOUZA, Juliete Gomes de Lara de ${ }^{1}$; TOLEDO, Adrieli Gorlin ${ }^{1}$; SANTANA, Camila \\ Beatriz $^{1}$; SANTOS, Camila Vogt dos ${ }^{1}$; MALLMANN, Ana Paula ${ }^{1}$; SILVA, Jéssica \\ Patrícia Borges da ${ }^{2}$; PINTO, Fabiana Gisele da Silva ${ }^{1^{*}}$
}

\footnotetext{
${ }^{1}$ Universidade Estadual do Oeste do Paraná, Laboratório de Biotecnologia, Programa de Conservação e Manejo de Recursos Naturais, Cascavel, Paraná, Brasil.

${ }^{2}$ Universidade Estadual do Oeste do Paraná, Centro de Ciências Biológicas e da Saúde, Programa de Conservação e Manejo de Recursos Naturais, Cascavel, Paraná, Brasil.

*Endereço para correspondência: fabiana.pinto@unioeste.br
}

\section{SUMMARY}

The present study aimed to identify and quantify the components of the essential oil of Zanthoxylum caribaeum and to evaluate the antimicrobial potential of different plant extracts and the essential oil of this plant against different serotypes of Salmonella enterica, which is of greater occurrence and isolated in the western region of Paraná, Brazil. The extraction of the essential oil was performed using Clevenger apparatus and the chemical composition was determined by Gas Chromatography coupled to Mass Spectrometry (GC-MS). The extracts were obtained through different solvents (ethanol, methanol, hexane, acetone, dichloromethane, ethyl acetate and distilled water). The antibacterial activity was carried out according to the broth microdilution technique. The GC-MS analysis resulted in the identification of 15 main components, all terpenes, representing $63.88 \%$ of the total essential oil. The major compounds identified were Germacrene-D (20.77\%), $\alpha$-Panasinsene $(14.40 \%)$ and $\beta$-Selinene $(11.68 \%)$. The essential oil presented antibacterial activity against 5 serotypes of Salmonella enterica, with MIC and MBC ranging from 7000 to 437 $\mu \mathrm{g} . \mathrm{mL}^{-1}$. While $\mathrm{MIC}$ and $\mathrm{MBC}$ from the range from 200 to $25 \mathrm{mg} \cdot \mathrm{mL}^{-1}$, being effective to most serotypes of $S$. enterica, with the exception of the aqueous extract. The results suggest that the essential oil and leaf extracts of $Z$. caribaeum represent an alternative for the control of $S$. enterica in the poultry sector, in this way reflecting a new perspective for studies with natural products.

Keywords: minimum bactericidal concentration, minimum inhibitory concentration, gas chromatography, microdilution, natural products

\section{RESUMO}

Objetivou-se com este estudo identificar e quantificar os constituintes do óleo essencial de Zanthoxylum caribaeum e avaliar o potencial antimicrobiano de diferentes extratos vegetais e do óleo essencial desta planta frente a diferentes sorotipos de Salmonella enterica, de maior ocorrência e isoladas na região oeste do Paraná, Brasil. A extração do óleo essencial foi realizada utilizando aparelho Clevenger e a composição química foi determinada por Cromatografia Gasosa acoplada a Espectrometria de Massas (CG-EM). Os extratos foram obtidos através de diferentes solventes (etanol, metanol, hexano, acetona, diclorometano, acetato de etila e água destilada). A atividade antibacteriana foi realizada segundo a técnica de microdiluição em caldo. As análises de CG-EM resultaram na identificação de 15 constituintes principais, todos terpenos, representando $63,88 \%$ do total de óleo essencial. Os compostos majoritários 
identificados foram Germacreno-D (20,77\%), $\alpha$-Panasinseno $(14,40 \%)$ e $\beta$-Selineno $(11,68$ $\%)$. O óleo essencial apresentou atividade antibacteriana frente a 5 sorotipos de Salmonella enterica, com CIM e CBM variando de 7000 a $437 \mu \mathrm{g} . \mathrm{mL}^{-1}$. Já os extratos variam a CIM e CBM de 200 a 25 mg. $\mathrm{mL}^{-1}$, sendo eficazes para a maioria dos sorotipos de $S$. enterica, com exceção do extrato aquoso. Os resultados sugerem que o óleo essencial e os extratos das folhas de $Z$. caribaeum representam uma alternativa para o controle de $S$. enterica, no setor avícola, refletindo uma nova perspectiva para estudos com produtos naturais.

Palavras-chave: concentração bactericida mínima, concentração inibitória mínima, cromatografia gasosa, microdiluição, produtos naturais

\section{INTRODUCTION}

Foodborne pathogens are widely diverse in nature and continue to be the major cause of global public health problems in both developed and developing countries. Among these pathogens is Salmonella, responsible for costs with medical care, loss of productivity and expenses with control by the food industry and, mainly, problems for the poultry industry (MAJOWICZ et al., 2010).

The Enteric serotypes usually are the disease causative, such as aviary paratyphoid, with Salmonella enterica subsp. enterica ser. Enteritidis and $S$. Typhimurium, which stand out in this subgroup, because they are important cause of problems related to food infections in humans (OLIVEIRA et al., 2013), especially in regard to poultry originated products, since eggs and meat are the main transmission path of the disease (KOTTWITZ et al., 2008).

In view of the above, natural products such as extracts and essential oils are an excellent resource for the search of new bioactive substances with biological potential, since they have a superior molecular diversity to synthetic products (SIQUEIRA et al., 2014).

The plant Zanthoxylum caribaeum Lam.belongs to the Rutaceae family, with more than 500 species it has worldwide distribution mainly in tropical and subtropical regions. $Z$. caribaeum is popularly known as espinho-preto (PIRANI\& GROPPO, 2015) and has been widely used by the population for its anti-inflammatory properties (VILLALBA et al., 2007). It should be emphasized that there are few studies with this species and none of them are related to the biological action of it. However, according to Patinõ \& Cuca (2011) Zanthoxylum spp. have such a broad ethnobotanical and biological importance, thus a promising source of substances with different biological activities.

Based on this context, the present study aimed at the chemical characterization of the essential oil and evaluation of the antibacterial activity of the oil and plant extracts of $Z$. caribaeum against different serotypes of Salmonella of poultry origin with higher incidence in the western region of Paraná, Brazil.

\section{MATERIAL AND METHODS}

The experimental analyses were carried out at the Agricultural Biotechnology Laboratory in West of Paraná State University. The Leaves of $Z$. caribaeum were collected from January to April 2015, in the Paulo Gorski ecological park, situated in Cascavel city in the west of Paraná state, Brazil (24 57'51" S $\left.53^{\circ} 26^{\prime} 2^{\prime \prime} \mathrm{W}\right)$. An exsicate of the plant was incorporated in the West of Paraná State University Herbarium (UNOP) for botanical identification and registration 
of the voucher, under the number UNOP 1849.

For the essential oil extraction, $60 \mathrm{~g}$ of fresh Z. caribaeum plant material was added in $700 \mathrm{~mL}$ of distilled water and submitted to extraction by hydrodistillation for four hours using a Clevenger-type apparatus (SILVA et al., 2012). The essential oil collected was, dried over in hydrated sodium sulphate $(\sim 1 \mathrm{~g})$, and stored under refrigeration and shelter from light at an average temperature of $4^{\circ} \mathrm{C}$ until analyzed.

The constituents of the essential oil were identified through gas chromatography coupled to mass spectrometry (GC-MS) and the identification of the compounds was performed by comparing their retention times with the retention times obtained in the literature (ADAMS, 2007).

To prepare the extracts, the leaves of $Z$. caribauem were dried and milled in knife mills according to Weber et al. (2014). For the preparation of the aqueous extract, $10 \mathrm{~g}$ of crushed plant material were added to $100 \mathrm{~mL}$ of distilled water. This mixture was kept on a rotary shaker at $220 \mathrm{rpm}$ for 24 hours. After this period, the solution was filtered using Whatman $\mathrm{n}^{\circ}$. 1 paper filter and centrifuged for 15 minutes at 5000 rpm. The supernatant was collected, thus obtaining the extract at the final concentration of $100 \mathrm{mg} \cdot \mathrm{mL}^{-1}$. The extract was stored at $4{ }^{\circ} \mathrm{C}$. The organic extracts were prepared according to Pandini et al. (2015) with modifications, ethanol (EtOH), methanol $(\mathrm{MeOH})$, hexane (Hex), acetone (AcOH), dichloromethane $\left(\mathrm{CH}_{2} \mathrm{Cl}_{2}\right)$ and ethyl acetate (EtOAc) were used as solvents.

Ten grams of ground vegetable material was added to $100 \mathrm{~mL}$ of the desired organic solvent, the solution then was maintained on a rotary shaker at $220 \mathrm{rpm}$ for 24 hours. The solution was filtered using Whatman $\mathrm{n}^{\mathrm{o}}$. 1 paper filter and centrifuged for 15 minutes at $5000 \mathrm{rpm}$. After collection of the supernatant, the extracts were submitted torotaevaporation. The crude extracts were diluted in $10 \%$ dimethylsulfoxide (DMSO) until a final concentration of $400 \mathrm{mg} \cdot \mathrm{mL}^{-1}$ and then stored at $4{ }^{\circ} \mathrm{C}$.

To evaluate the antibacterial activity, 11 serotypes of Salmonella enterica subsp. enteric of greater occurrence in the western region of the State of Paraná, Brazil: $S$. Enteritidis, $S$. Infantis, $S$. Typhimurium, $S$. Mbandaka, $S$. Orion, $S$. Shwarzengrund, $S$. Cubana, $S$. Montevideo, $S$. Senftenberg, $S$. Grumpensis e $S$. Tennessee provided by the veterinary laboratory MercoLab, Cascavel, Paraná, Brazil.

The minimum inhibitory concentration (MIC) of the essential oil and plant extracts was determined according to the broth microdilution method proposed by Scur et al. (2014). For the tests, each bacterial suspension was standardized with $1 \times 10^{5}$ UFC. $\mathrm{mL}^{-1}$ concentration. Both the essential oil and the plant extracts were solubilized in methanol $(100 \%)$ and Mueller-Hinton broth (MHB). For the oil, concentrations were tested ranging from 7000 to $1.68 \mu \mathrm{g} . \mathrm{mL}^{-}$ 1 and for plant extracts, concentrations of 200 to 0.09 mg.mL- ${ }^{1}$. Microbial wells were reserved for control of broth sterility (MHB only), bacterial growth (bacterial suspension and MHB), reference antimicrobial action (bacterial suspension, MHB and gentamicin 200 mg.mL ${ }^{-1}$ ) and solvent (bacterial suspension, MHB and methanol). From the wells that showed no visible bacterial growth prior to the addition of TTC $10 \%$ (triphenyltetrazolium chloride) (SCUR et al., 2014), an aliquot of $2 \mu \mathrm{L}$ was drawn out and inoculated on the surface of $\mathrm{MH}$ agar medium. The plaques were incubated for 24 hours at $36 \pm 0.1^{\circ} \mathrm{C}$. After this period, MBC was defined as the lowest concentration of essential oil 
capable of causing the death of the inoculum (PANDINI et al., 2015).

The MIC and MBC of the essential oil and the extracts were classified according to the criteria proposed by Sartoratto et al. (2004). For the essential oil, the activity was classified as high (between 50-500 $\mu \mathrm{g} \cdot \mathrm{mL}^{-1}$ ), moderate (between 600 a $1.500 \mu \mathrm{g} \cdot \mathrm{mL}^{-1}$ ), low (above $1.500 \mu \mathrm{g} \cdot \mathrm{mL}^{-1}$ ). For the extracts, the classification was high $(\leq 12.5$ mg.mL $\left.{ }^{-1}\right)$, moderate $(12.5$ a 25 mg.mL $\left.{ }^{1}\right)$, low $\left(50\right.$ a $\left.100 \mathrm{mg} \cdot \mathrm{mL}^{-1}\right)$ e very low $\left(>100 \mathrm{mg} \cdot \mathrm{mL}^{-1}\right)$ Pandini et al. (2015).

\section{RESULTS AND DISCUSSION}

The essential oil output obtained through hydrodistillation was $1,24 \%$ for $Z$. caribaeum. Of the chemical constituents detected in the leaves essential oil, 60,92 $\%$ was sesquiterpenes e 2,96\% monoterpenes, representing a total of $63,88 \%$, the majority compounds being Germacrene D (20,77\%), $\alpha$-Panasinsene $(14,40 \%)$ and $\beta$-Selinene $(11,68 \%)$ (Table 1).

Table 1. Chemical composition of the essential oil of the leaves of Z. caribaeum obtained by hydrodistillation e analised by $G C-M S$

\begin{tabular}{|c|c|c|c|c|c|}
\hline $\mathrm{N}^{0}$ & Compound & TR & Área (\%) & IK & $\mathrm{IK}^{*}$ \\
\hline 1 & $\beta$ - Mircene & 16.72 & 0.70 & 986.9 & $981(1)$ \\
\hline 2 & p-Cimene & 18.94 & 0.51 & 1020.0 & $1025(1)$ \\
\hline \multirow[t]{2}{*}{3} & D-Limonene & 19.23 & 0.42 & 1024.2 & $1029(3)$ \\
\hline & Hydrocarbonated Monoterpenes & & 1.63 & & \\
\hline 4 & $\alpha$-Felandrene & 17.68 & 0.23 & 1002.0 & $993(1)$ \\
\hline \multirow[t]{2}{*}{5} & Eucalyptol & 19.41 & 1.10 & 1026.8 & $1034(2)$ \\
\hline & Oxygenated Monoterpenes & & 1.33 & & \\
\hline 6 & Copaene & 42.68 & 0.46 & 1367.3 & $1370(1)$ \\
\hline 7 & $\beta$-Bourbonene & 43. 16 & 0.39 & 1374.5 & $1374(1)$ \\
\hline 8 & $\beta$-Elemene & 43.65 & 4.38 & 1381.9 & $1389(4)$ \\
\hline 9 & Cariofilene & 47.58 & 0.56 & 1444.4 & $1410(1)$ \\
\hline 10 & Germacrene $\mathrm{D}^{* *}$ & 49.17 & 20.77 & 1470.2 & $1476(6)$ \\
\hline 11 & $\beta$-Selinene** & 49.35 & 11.68 & 1473.2 & $1483(1)$ \\
\hline 12 & Eremofilene & 49.86 & 6.33 & 1481.5 & $1486(5)$ \\
\hline \multirow[t]{2}{*}{13} & $\alpha-P a n a s i n s e n e^{* *}$ & 51.40 & 14.40 & 1506.8 & $1518(4)$ \\
\hline & Hydrocarbonated Sesquiterpenes & & 58.97 & & \\
\hline 14 & Espatulenol & 54.76 & 1.29 & 1564.2 & $1563(1)$ \\
\hline \multirow[t]{2}{*}{15} & $\alpha$-Cadinol & 59.28 & 0.66 & 1643.9 & $1642(1)$ \\
\hline & Oxygenated Sesquiterpenes & & 1.95 & & \\
\hline \multirow[t]{2}{*}{16} & Non Identified & 50.06 & 20.30 & 1488.9 & - \\
\hline & Total of compounds & & 84.18 & & \\
\hline
\end{tabular}

Among the eleven serotypes of Salmonella test, five were susceptible to the leaves essential oil of $Z$. caribaeum in the tested concentrations (Table 2). The essential oil showed inhibition to the serotypes Mbandaka Shwarzengrund Cubana, Senftenberg e Enteritidis, while the best action was reported about the serotype Senftenberg with a MIC 437.5 $\mu \mathrm{g} \cdot \mathrm{mL}^{-1}$ and $\mathrm{MBC} 1750 \mu \mathrm{g} \cdot \mathrm{mL}^{-1}$, so the 
activity was considered elevated, according to the criteria of Sartoratto et al. (2004).

$\begin{array}{ll}\text { Table 2. } & \text { Minimum Inhibitory } \\ \text { Concentration (MIC) e } & \text { Minimum Bactericidal } \\ \text { Concentrarion (MBC) of the } \\ \text { leaves essential oil of } Z \text {. } \\ \text { caribaeum against serotypes of } \\ \text { Salmonella enterica }\end{array}$

\begin{tabular}{lc}
\hline Serotype & MIC / MBC $\left(\mu \mathrm{g} \cdot \mathrm{mL}^{-1}\right)$ \\
\hline Mbandaka & $7000 / 7000$ \\
Shwarzengrund & $1750 /-$ \\
Cubana & $3500 / 7000$ \\
Senftenberg & $437 / 1750$ \\
Enteritidis & $7000 / 7000$
\end{tabular}

(-) No Activity

Nanasombat \& Wimuttigosol (2011) also demonstrated antimicrobial potential within the genus Zanthoxylum, being the essential oil of the species $Z$. limonella showing a MIC of $20 \mathrm{mg} \cdot \mathrm{mL}^{-}$ 1 against the serotype $S$. Rissen. According to Gutierrez et al. (2008) this diversity of combinations of chemical constituents, presented by the essential oils, can manage to control bacteria that show consistently high resistance to antimicrobial agents, such as the case of the Salmonella genus.

The chemical profile of the oil revealed a high proportion of sesquiterpenes, especiallyhydrocarbonated

sesquiterpenes. The essential oils, due to the lipophility of this substances of terpenic structure, allows the breaking of cell membrane lipids, thus increasing the permeability of the same (BAKKALI et al., 2008). This feature can increase the action of antimicrobials in cell interior, so justifying the activity encountered for the different serotypes of Salmonella.
However, the compounds that are found in lesser quantity, like in this case $\alpha$ Felandrene e D-Limonene, can too contribute to the antimicrobial activity of the oils, it's possible they are involved in a synergic action with other active compounds (FRUTUOSO et al., 2013).

The plant extracts that showed the best results in relation to de antimicrobial activity against the tested salmonellas were $\mathrm{AcOH}$, AcEt e $\mathrm{MeOH}$, because all of the eleven serotypes analised showed themselves sensitive to them (Table 3). The aqueous extract showed bacteriostatic activity only for S.Mbandaka, while the Hex and $\mathrm{CH}_{2} \mathrm{Cl}_{2}$ extracts didn't show inhibitory action, only against the serotype $S$. Infantis. However, EtOH extract presented antimicrobial activity to $81.81 \%(9 / 11)$ of the serotypes tested, with the excpetion of $S$. Tennessee and $S$.Enteritidis.

It was verified that, in general, AcEt extract presented the best values of MIC and $\mathrm{MBC}$ for the different serotypes of Salmonella which varied from 25 to 50 $\mathrm{mg} \cdot \mathrm{mL}^{-1}$, when compared to the other extracts, it's activity being considered moderate to low. However, the serotypes Grumpensis e Tennessee (25 e 50 mg.mL ${ }^{-}$ ${ }^{1}$ ) presented the most sensitivity to $\mathrm{MeOH}$ extract.

In the literature, wasn't found studies regarding the antimicrobial activity of the plant extracts of $Z$. caribaeum against the serotypes of Salmonella. However, Zhang et al. (2014) reported the antimicrobial potencial whitin the genus against Gramnegative bacteria. According to the autors, ethanolic extract, ethyl acetate, acetone and methanolic of Zanthoxylum bungeanum showed MIC of $4.61 \mathrm{mg} . \mathrm{mL}^{-}$ 1, $2.32 \mathrm{mg} \cdot \mathrm{mL}^{-1}, 5.7 \mathrm{mg} \cdot \mathrm{mL}^{-1}$ and 3.1 $\mathrm{mg} \cdot \mathrm{mL}^{-1}$, respectively, against the strain E. coli, corroborating with our study. 
Table 3. Minimum Inhibitory Concentration (MIC) e Minimum Bactericidal Concentrarion (MBC) of the different leaves extract of $Z$. caribaeum against the serotypes of Salmonella enteric

\begin{tabular}{lccccccc}
\hline \multirow{2}{*}{ Serotype } & $\mathrm{AcOH}$ & $\mathrm{AcEt}$ & $\mathrm{EtOH}$ & $\mathrm{Hex}$ & $\mathrm{MeOH}$ & $\mathrm{CH}_{2} \mathrm{Cl}_{2}$ & $\mathrm{Aq}$ \\
\cline { 2 - 7 } & $200 / 200$ & $25 / 50$ & $25 / 50$ & - & $100 / 100$ & - & - \\
\hline Infantis & $100 / 100$ & $25 / 50$ & $50 / 50$ & $100 / 200$ & $25 / 100$ & $200 / 200$ & $200 /-$ \\
Mbandaka & $50 / 50$ & $25 / 25$ & $50 / 50$ & $50 / 100$ & $25 / 50$ & $200 / 200$ & - \\
Orion & $100 / 100$ & $25 / 50$ & $50 / 50$ & $100 / 200$ & $25 / 50$ & $100 / 200$ & - \\
Shwarzengrund & $25 / 50$ & $25 / 25$ & $50 / 50$ & $100 / 100$ & $100 / 100$ & $200 / 200$ & - \\
Cubana & $25 / 50$ & $25 / 50$ & $100 / 100$ & $100 / 100$ & $25 / 50$ & $100 / 200$ & - \\
Typhimurium & $50 / 50$ & $25 / 25$ & $50 / 50$ & $100 / 200$ & $50 / 50$ & $200 / 200$ & - \\
Montevideo & $25 / 100$ & $50 / 50$ & $50 / 50$ & $200 / 200$ & $50 / 100$ & $200 / 200$ & - \\
Senftenberg & $100 / 200$ & $50 / 50$ & $200 / 200$ & $100 / 200$ & $25 / 50$ & $200 / 200$ & - \\
Grumpensis & $50 / 50$ & $50 / 50$ & - & $100 / 200$ & $25 / 50$ & $200 / 200$ & - \\
Tennessee & $100 / 100$ & $25 / 25$ & - & $100 / 100$ & $25 / 50$ & $100 / 200$ & - \\
Enteritidis & & & -
\end{tabular}

Ethanolic extract (EtOH); Metanolic extract $(\mathrm{MeOH})$; Hexanic extract (Hex); Acetone extract $(\mathrm{AcOH})$; Dichloromethanic extract $\left(\mathrm{CH}_{2} \mathrm{Cl}_{2}\right)$; Ethyl acetate extract (AcEt); Aquous extract (Aq); (-) No activity.

Among the extracts tested, the AcEt presented wide spectrum of antimicrobial action, showing activity for different serotypes of Salmonella. The AcEt is a solvent of medium polarity, a trait that enables the extraction of the following chemical classes: flavonoids, tanines, xanthenes, triterpenic acids, saponines and fenolic compounds in general (CECHINELFILHO \& YUNES, 1998). The antimicrobial activities of some plant extracts are due to the high grade of fenolic compounds (AL-HABIB et al., 2010; KUMAR et al., 2011).

Still, it can be noticed that the usage of solvents with different polarities in the achievment of the extracts, promoted a diferenciated antimicrobial activity, being that such activity might be related to the action of several phytochemical constituents of the plant. Therefore, raw extracts of vegetal species can. many times, present a freater antimicrobial action against pathogens, due to the sinergism between the bioactive compounds that are extracted by the solvent or according the method of extraction emplyed (LEE \& LEE, 2010; DELGADO-ADÁMEZ et al., 2012).

Besides that, the different susceptibility presented by the serotypes of Salmonella enterica is commonly reported in the literature, can be explained by the defense mechanisms present in this Gram-negative bacteria. This elevated genetic variability that genus Salmonella exhibit, is resulting of a dynamic interaction between the pathogens, the environment and the different hosts (LIU et al., 2011; SCUR et al., 2016).

Lastly, it is concluded that the essential oil and the plant extracts of the leaves of $Z$. caribaeum present bioactive constituents with antimicrobal activity for different serotypes of Salmonella enterica, suggesting its future potentialities for the poultry sector, in search of safety and quality of the food consumed, as well as, new perspectives for studies with natural products in the industry. 


\section{REFERENCES}

\section{ADAMS, R.P. Identification of}

Essential oil Components by Gas

Chromatography/Mass

Spectrometry. 4 ed. Carol Stream, Illinois: Allured Publishing

Corporation, 2007. 804p.

\section{AL-HABIB A.; AL-SALEH E.; SAFER,} A.; AFZAL, M. Bactericidal effects of grape seed extracts on methicillinresistant Staphylococcus aureus (MRSA). The Journal of Toxicological Sciences [online], v.35, p.357-364, 2010.

BAKKALI, F.; AVERBECK, S.; AVERBECK, D.; IDAOMAR, M. Biological effects of essential oil: a review. Food and Chemical Toxicology [online], v.46, n.2, p.446-75, 2008.

CECHINEL-FILHO, V.; YUNES, R.A. Estratégias para a obtenção de compostos farmacologicamente ativos a partir de plantas medicinais: conceitos sobre modificação estrutural para otimização da atividade. Química Nova [online], v.21, n.1, p.99-105, 1998.

DELGADO-ADÁMEZ, J.; FERNANDEZ-LEON, M.F.; VELARDO-MICHARET, B.; GONZALEZ-GOMEZ, D. In vitro assays of the antibacterial and antioxidant activity of aqueous leaf extracts from different Prunus Salicina Lindl. cultivars. Food and Chemical Toxicology [online], v.50, p.2481-2486, 2012.

FRUTUOSO, A.E.; NASCIMENTO, N.T. do; LEMOS, T.L.G.; COELHO, E.L.; TEIXEIRA, D.M.A. Óleos essenciais aplicados em alimentos: Uma revisão. Revista Brasileira de Pesquisa em Alimentos [online], v.4, n.2, p.69-81, 2013.
GUTIERREZ, J.; BARRY-RYAN, C.; BOURKE, $P$. The antimicrobial efficacy of plant essential oil combinations and interactions with food ingredients. International Journal of Food Microbiology, v.124, n.1, p.91-97, 2008.

KOTTWITZ, L.B.M.; BACK, A.; LEÃO, J.A.; ALCOCER, I.; KARAN, M.; OLIVEIRA, T.C.R.M. Contaminação por Salmonella spp. em uma cadeia de produção de ovos de uma integração de postura comercial. Arquivo Brasileiro de Medicina Veterinária e Zootecnia[online], v.60, n.2, p.496-498, 2008.

KUMAR, K.A.; NARAYANI, M.; SUBANTHINI, A.; JAYAKUMAR, M. Antimicrobial activity and phytochemical analysis of citrus fruit peels - utilization of fruit waste. International Journal of Engineering Science and Technology [online], v.3, p.5414-5421, 2011.

LEE, O.H., LEE, B.Y. Antioxidant and antimicrobial activities of individual and combined phenolics in Oleaeuropaea leaf extract. Bioresource Technology [online], v.101, n.10, p.3751-3754, 2010.

LIU, W.; LIU, B.; ZHU, X.; YU, S.; SHI, $\mathrm{X}$. Diversity of Salmonella isolates using serotyping and multilocus sequence typing. Food Microbiology [online], v.28, n.6, p.1182-1189, 2011.

MAJOWICZ, S.; MUSTO, J.; SCALLAN, E.; ANGULO, F.J.; KIRK, M.; O'BRIEN, S.J.; JONES, T.F.; FAZIL, A.; HOEKSTRA, R.M. The global burden of nontyphoidal Salmonella gastroenteritis. Clinical Infectious Diseases [online], v.50, n.6, p.882-889, 2010.

NANASOMBAT, S.;

WIMUTTIGOSOL, P. Antimicrobial and antioxidant activity of spice essential oils.

Food Science and Biotechnology

[online], v.20, n.1, p.45-53, 2011. 
OLIVEIRA, A.P.; SOLA, M.C.;

FEISTEL, J.C.; MOREIRA, N.M.; OLIVEIRA, J.J. Salmonella enterica: genes de virulência e ilhas de patogenicidade. Enciclopédia Biosfera, Centro Científico Conhecer [online], v.9, n.16, p.1947-1972, 2013.

PANDINI, J.A.; PINTO, F.G.S.; SCUR, M.C.; ALVES, L.F.A; CASTILHO, C.M. Antimicrobial, insecticidal, and antioxidante activity of essential oil and extracts of Guarea kunthiana A. Juss.

Journal of Medicinal Plant Research, v.9, n.3, p.48-55, 2015.

PATINÕ, O.J.; CUCA, O.J.

Monophyllidin, a new alkaloid L-proline derivative from Zanthoxylum monophyllum. Phytochemistry Letters [online], v.4, n.1, p.22-25, 2011.

PIRANI, J.R.; GROPPO, M. Rutaceae. In:Lista de Espécies da Flora do Brasil. Jardim Botânico do Rio de Janeiro, 2015. Disponível em:

$<$ http://floradobrasil.jbrj.gov.br/jabot/flora dobrasil/FB212>. Acesso em: 03 mar 2017.

\section{SARTORATTO, A. ; MACHADO,}

A.L.M.; DELARMELINA, C.; FIGUEIRA, G.M.; DUARTE, M.C.T.; REHDER, V.L.G. Composition and antimicrobial activity of essential oils from aromatic plants used in Brazil.

Brazilian Journal of Microbiology [online], v.35, n.4, p.275-280, 2004.

SCUR, M.C.; PINTO, F.G.S.; BONA, E.A.M.; WEBER, L.D.; ALVES, L.F.A.; MOURA, A.C. Occurrence and antimicrobial resistance of Salmonella serotypes isolates recovered from poultry of Western Paraná, Brazil. African Journal of Agricultural Research [online], v.9, n.9, p.823-830, 2014.
SCUR, M. C.; PINTO, F. G. S.; BONA, E.A.M.; WEBER, L.D.; FRUET, T.K.; SORESINI, G.C.G. Atividade de desinfetantes frente a sorotipos de Salmonella isolados de granjas avícolas. Revista Brasileira de Saúde e Produção Animal [online], v.17, n.4, p.677-684, 2016.

SILVA, T.R.G.; MARTINS, T.D.D.; SILVA, J.H.V.; SILVA, L.P.G.; PASCOAL, L.A.F.; OLIVEIRA, E.R.A.; BRITO, M.S. Inclusão de óleos essenciais como elementos fitoterapicos na dieta de suínos. Revista Brasileira de Saúde e Produção Animal [online], v.13, n.1, p. 181-191, 2012.

SIQUEIRA M.P.; CANDIDO, F.S.; AMARAL, T.M. do; MOREIRA, D.L. Atividade larvicida de extratos, frações e substâncias isoladas de espécies de Piperaceae do Estado do Rio de Janeiro. Boletim Informativo Geum [online], v.5, n.2, p.35-43, 2014.

VILLALBA, M. A.; CARMO, M. I.; LEITE, M. N.; SOUSA, O. V. Atividades farmacológicas dos extratos de

Zanthoxylum chiloperone (Rutaceae). Revista Brasileira de Farmacognosia [online], v.17, n.2, p.236-241, 2007.

WEBER, L.D.; PINTO, F.G.S.; SCUR, M.C.; SOUZA, J.G.L.; COSTA, W.F.; LEITE C.W. Chemical composition and antimicrobial and antioxidant activity of essential oil and various plant extracts from Prunus myrtifolia (L.) Urb. African Journal of Agricultural Research [online], v.9, n.9, p.846-853, 2014.

ZHANG, Y., LUO, Z., WANG, D., HE, F., LI, D. Phytochemical profiles and antioxidant and antimicrobial activities of the leaves of Zanthoxylum bungeanum. The Scientific World Journal [online], v.2014, n.2014, p.1-13, 2014.

Data de recebimento: 15/05/2017

Data de aprovação: 14/08/2017 